\author{
Nikolay Bulychev ${ }^{1,2}$, Edward Kisterev ${ }^{1}$,Yulia Ioni ${ }^{1}$, Ondine Confortini ${ }^{3}$, Filip Du Prez ${ }^{3}$, Vitali \\ Zubov, and Claus Eisenbach ${ }^{2,5}$.
}

\title{
SURFACE MODIFICATION IN AQUEOUS DISPERSIONS WITH THERMO-RESPONSIVE POLY(METHYLVINYLETHER) COPOLYMERS IN COMBINATION WITH ULTRASONIC TREATMENT
}

\author{
1 N.S. Kurnakov Institute of General and Inorganic Chemistry of Russian Academy of Sciences, \\ 31 Leninsky Ave., 119991 M oscow, Russia \\ 2 Institute for Polymer Chemistry, University of Stuttgart, 55 Pfaffenwaldring, D-70569 Stuttgart, Germany \\ 3 Department of Organic Chemistry, Polymer Chemistry Research Group, Ghent University, \\ Krijgslaan 281 S4, B-9000 Ghent, Belgium \\ 4 Lomonosov M oscow State Academy of Fine Chemical Technology, \\ 86 Vernadskogo Ave., 117571 M oscow, Russia \\ 5 Research Institute for Pigments and Coatings, 37Allmandring, D-70569 Stuttgart, Germany
}

Received: M arch 19, 2010 / Revised: June 26, 2010 / Accepted: December 17, 2010

(c) Bulychev N., Kisterev E., Ioni Yu., Confortini O., Du Prez F., Zubov V., Eisenbach C., 2011

\begin{abstract}
The process of surface modification of hydrophobic organic pigments (copper phthalocyanine (CuPc) and carbon black) as well as a hydrophilic inorganic pigment (titanium dioxide) in aqueous dispersions by employing tailor-made thermo-responsive copolymers, and the colloidal stability have been studied. The pigment surface modification is achieved by conventional adsorption and by (thermo)precipitation of amphiphilic methyl vinyl ether (MVE) containing polyvinylether block and PMVE graft copolymers with poly(ethylene oxide) side chains exhibiting a lower critical solution temperature (LCST). The effect of mechanical treatment of the pigment dispersion by ultrasonic power alone or in combination with the LCST property was investigated. The course of the pigment surface coating process was followed by the Electrokinetic Sonic Amplitude (ESA) method. The temperature-controlled sorption of PMVE-g-PEO graft copolymers on both inorganic and organic pigment surface was investigated. It was found that ultrasonic treatment together with LCST thermoprecipitation is a promising method for the surface modification of pigments with regard to dispersion stability.
\end{abstract}

\section{Introduction}

In recent years, polymer surfactants have been of increasing interest as stabilizers for particulate systems, especially for emulsions and suspensions. Aqueous colloidal dispersions of pigments are important, ecologically friendly colloidal systems widely used in polygraphic and paint industries. The pigment particles are usually of 20-200 nm diameter and may be quite hydrophobic. In order to achieve a good stabilization in aqueous pigment dispersions, many formulations were proposed [1-8]. Earlier we reported about the role of mechanical, e.g. ultrasonic treatment to obtain highly stable dispersions [7, 9]. It was shown that using of polymer surfactants in combination with ultrasonic action can significantly improve the quality of dispersed systems. However, some aspects concerning pigment-polymer interaction and formation of adsorption layers under mechanical action needed additional elucidation.

The colloid stabilization of aqueous dispersions with polymer surfactants is believed to be a consequence of adsorption of the amphiphilic macromolecules on the particle surface resulting in mono- or multi-layers of certain structure and thickness which provide certain sterical and/or electrostatic stabilization effects. Polymer adsorption from aqueous solution on a particle surface is a result of specific interactions of various active sites on the particle surface with corresponding sites (groups) of the macromolecule. Therefore the chemical structures of the stabilizers are believed to be adjusted to the nature (e.g. hydrophilicity, charge etc.) of each type of the particles.

Thermo-responsive "smart" polymers exhibiting lower critical solution temperature (LCST) in aqueous solutions change the hydrophilic-hydrophobic balance when passing through LCST (they become more hydrophobic above LCST). One can expect that this property may result in temperature-controlled sorption and structure of the 
adsorption layer, and thus allowing colloid stabilization of aqueous dispersions. In other words, temperature-controlled changes in the hydrophobic-hydrophilic balance of those "smart" polymers can be used to adjust surfactant behavior of the polymer in order to achieve colloidal stabilization effects for various particles without changes of chemical structure or composition of the stabilizer.

Detailed information about the interaction of copolymers with the pigment surface, e.g., adsorption/ desorption phenomena as reflected from the dynamic mobility $\mu_{D}$ of the dispersed particle, can be obtained by applying the Electrokinetic Sonic Amplitude (ESA) technique [10-17]. With this method, a potential is measured from pressure waves generated by the movement of charged particles in an oscillating electric field. The variation of this potential with frequency can be used for determining $\mu_{D}$ of particles reflecting the formation of thin polymer layers on their surface and for calculating the zeta potential as well as the particle size. For fixed low frequencies as applied in this work, $\mu_{D}$ is affected by the surface charge of the particle only [16, 18-20]. The study of the change of the dynamic mobility $\mu_{D}$ of aqueous $\mathrm{TiO}_{2}$ dispersion upon addition of amphipolar polyelectrolytes has shown that ESA is a powerful method to reveal the course of polymer-pigment interactions and how this is related to the molecular architecture of the employed polyelectrolytes [19, 20].

\section{Experimental}

\subsection{M aterials}

As pigments, $\beta$-copper phthalocyanine $(\beta$-CuPc $)$ with primary particle size $0.1 \mu \mathrm{m}$ and carbon black (channel type) FW 285 with primary particle size $11 \mathrm{~nm}$ were chosen. The PMVE-copolymers of various welldefined structures, molecular weights and narrow polydispersities, were synthesized by "living" cationic polymerization techniques as described elsewhere [22].

\subsection{Techniques}

Colloidal stabilization of the aqueous dispersions was monitored by sedimentation measurements of $1 \%$ dis- persions of $\mathrm{CuPc}$ and carbon black. Block copolymers used for stabilization of $\mathrm{CuPc}$ are insoluble in water. Therefore, for the preparation of the aqueous dispersions, the polymers were predissolved in ethyl acetate (5\%) and then introduced to the aqueous phase together with the pigment (ethyl acetate:water volume phase ratio was 1:10) [22]. After mixing with a laboratory stirrer (700 rpm for $10 \mathrm{~min}$ ), the system was treated with ultrasound for 2 min with an ultrasonic generator UZDN-2 or Branson Sonifier B-12 with actual power of $1.5 \mathrm{~W} / \mathrm{cm}^{2}$. The pigment-polymer interaction was investigated by electrokinetic sonic amplitude (ESA) method. ESA measurements were carried out as described earlier [18]. Transmission electron microscopy (TEM) investigations were carried out according to the standard procedure. The samples of the pigment dispersions were diluted with distilled water by a factor of 100 , then dropped on the TEM grid of $3 \mathrm{~mm}$ diameter and dried on air for 1 day. The TEM pictures were taken by using a Jeol $2000 \mathrm{FX}$ device under the voltage of $200 \mathrm{kV}$.

\section{Results and Discussion}

\subsection{Pigment Surface Modification with Graft Copolymers}

\subsubsection{Sedimentation studies}

First, P(MVE-g-EO) graft copolymers with a PMVE backbone and PEO side chains have been investigated. These polymers are hydrophilic below the LCST of PMVE and become amphiphilic above the LCST of PMVE. Hydrophilic pigments $\left(e . g\right.$. $\left.\mathrm{TiO}_{2}\right)$ are known to need hydrophilic surfactants for stabilization in aqueous dispersions, whereas hydrophobic pigments $(\mathrm{CuPc}$ and carbon black) need amphiphilic polymers to achieve stabilization of their aqueous dispersions. This opens a perspective to use these PMVE graft copolymers as universal smart surfactants for surface modification of both polar inorganic and non-polar organic pigments by taking advantage of the temperature-controlled sorption.

Table 1

Sedimentation stability of $\mathrm{TiO}_{2}$ and $\mathrm{CuPc}$ aqueous dispersions with PMVE-g-PEO graft copolymers as a function of temperature

\begin{tabular}{|c|c|c|c|c|c|}
\hline \multirow{2}{*}{ Code } & \multirow{2}{*}{$\begin{array}{c}\text { Number of PEO } \\
\text { grafts/Mn }\end{array}$} & \multicolumn{4}{|c|}{ Half-time of sedimentation } \\
\cline { 3 - 6 } & & \multicolumn{2}{|c|}{$293 \mathrm{~K}$} & \multicolumn{2}{c|}{$323 \mathrm{~K}$} \\
\cline { 3 - 6 } & $9 / 2000$ & $\mathrm{TiO}_{2,}$ days & $\mathrm{CuPc}$, min & $\mathrm{TiO}_{2}$, min & CuPc, days \\
\hline $\mathrm{G} 1$ & $3 / 5000$ & 30 & - & $\uparrow$ & 7 \\
$\mathrm{G} 2$ & $3 / 5000$ & 30 & $10-15$ & $30-40$ & 20 \\
$\mathrm{G} 3$ & $7 / 5000$ & 25 & $\downarrow$ & $\downarrow$ & 23 \\
$\mathrm{G} 4$ & $13 / 5000$ & 25 & - & - & 20 \\
$\mathrm{G} 5$ & & & & & \\
\hline
\end{tabular}


The stabilizing activity of the series of PMVE-g$\mathrm{PEO}$ polymers in $\mathrm{TiO}_{2}$ and $\mathrm{CuPc}$ aqueous dispersions were investigated at different temperatures. The results are given in Table 1. The half-time of the sedimentation, i.e. the period of time which is necessary for the border between colored and transparent zones in sedimentation measurements to reach $50 \%$ of the test-tube height was chosen as a measure of the stabilization activity.

Below the LCST of PMVE all copolymers are hydrophilic and thus, as one can see from Table 1, with exception of $\mathrm{G} 1$ act as efficient stabilizers of $\mathrm{TiO}_{2}$ aqueous dispersions.

Regarding the relative difference of the hydrophilicity of the PEO grafts and the PMVE backbone it is assumed that the more hydrophilic PEO primarily interacts with the hydrophilic $\mathrm{TiO}_{2}$ surface; i.e. the PEO grafts act as anchors. As far as the interaction of the graft copolymer with the hydrophobic $\mathrm{CuPc}$ is considered, it is possible to assume a preferred interaction with the less hydrophilic PMVE backbone.

However, after increasing the temperature above the LCST of the PMVE block, fast coagulation occurs and the size of precipitating particles becomes about 7-8 $\mu \mathrm{m}$. This must be attributed to changes in the conformation of the PMVE backbone upon exceeding of the LCST (collapse of coil) and to interaction phenomena, i.e. the PMVE cannot act as a sterical stabilizing element anymore. As a consequence, the more hydrophilic PEO grafts which act as anchors at the $\mathrm{TiO}_{2}$ surface are immobilized and buried. This means a relative hydrophobization of the polymer layer around the $\mathrm{TiO}_{2}$ particle and particle coagulation causing sedimentation might result. On the other hand, a subsequent cooling below the LCST in combination with ultrasonic action allows to redisperse the system. The stability of the obtained dispersions is comparable to that of non-heated samples. This means that the agglomerates were broken by the action of ultrasonic power and that the PMVE backbone returned to the previous swollen state.

The poor colloidal stabilization with G1 polymer which contains only low molecular PEO segments is probably due to its weak adsorption on the $\mathrm{TiO}_{2}$ particles and may indicate that adsorption is mainly due to interaction of high molecular PEO segments with $\mathrm{TiO}_{2}$ surface. So one can conclude that PEO side chains of the copolymer are responsible for pigment-polymer interaction causing adsorption of PEO grafts on the pigment particles surface whereas the PMVE backbone allows for steric stabilization.

In the case of $\mathrm{CuPc}$ aqueous dispersions, reverse stabilization behavior is observed: above the LCST, all polymers act as stabilizers of $\mathrm{CuPc}$ aqueous dispersions, while fast coagulation is observed after temperature decrease to temperature below LCST.

This is attributed to the function of the collapsed PMVE backbone above the LCST as anchor to the CuPc surface. Comparing the hydrophilicity of PEO grafts and PMVE backbone below and above LCST, it is meaningful to assume that the collapsed PMVE above LCST is less hydrophilic than the expanded PMVE coil below LCST. This means that the exceeding of the LCST results in the formation of an amphiphilic copolymer with hydrophilic PEO coil and comparatively hydrophobic collapsed PMVE. As a consequence, above LCST the CuPc dispersion is stabilized by the interaction of "hydrophobic" collapsed PMVE with the CuPc surface.

When subsequently lowering the temperature below LCST, the adsorption of the graft copolymer on the CuPc surface is significantly weekend because of the dissolution (expanding) of the PMVE part of the graft copolymer which acts as anchor in the collapsed state only.

For both dispersion types, the best results are obtained for the graft copolymers with the longest PEO grafts (5000 vs. 2000). On the other hand, the number of grafts has not a significant influence on the sedimentation stability within the investigated range (between 3 and 13).

\subsubsection{Electrokinetic sonic amplitude (ESA) measurements}

The adsorption of the PMVE-g-PEO copolymers on the $\mathrm{TiO}_{2}$ and $\mathrm{CuPc}$ surface was investigated by the ESA method. For these measurements, the copolymer G3 (acting as the best stabilizer) was chosen (Figs. 1 and 2). Other copolymers showed similar results.

From Fig. 1 it is evident that the pigment-polymer suspensions show quite different behavior as a function of their preparation method. Without ultrasonic action, saturation of the surface adsorption layer seems to be reached at $1 \%$ of PMVE-g-PEO in relation to the pigment $\mathrm{TiO}_{2}$. After ultrasonic action, initial dynamic mobility of the $\mathrm{TiO}_{2}$ is much higher, and saturation concentration of polymer is only reached at about $5 \%$. The differences in the initial values of the dynamic mobility and following differences in its changes due to the sorption of the polymer can be attributed to mechanical activation of the surface with ultrasonic treatment. Further addition of polymer did not affect the dynamic mobility. Thus, comparing the saturation concentrations for mechanically treated and nontreated samples, one can conclude that the ultrasonic action not only increases the pigment surface due to the obtained finer dispersion, but also leads to a higher thickness of the adsorption layer in comparison to the non-treated samples.

As already described above, fast coagulation of the $\mathrm{TiO}_{2}$ dispersion was observed after exceeding the LCST of PMVE (Table 1). ESA examination of these coagulated dispersions enabled to prove that at the saturation concentrations, the dynamic mobility and $\xi$-potential of the particle surface did not change noticeably in comparison to those at room temperature; this indicates the absence of polymer desorption. This is also further prove of the earlier 
statement that pigment-polymer interaction at room temperature is apparently due to the adsorption of the PEO chains, while the PMVE backbones are preferably exposed into the aqueous media.

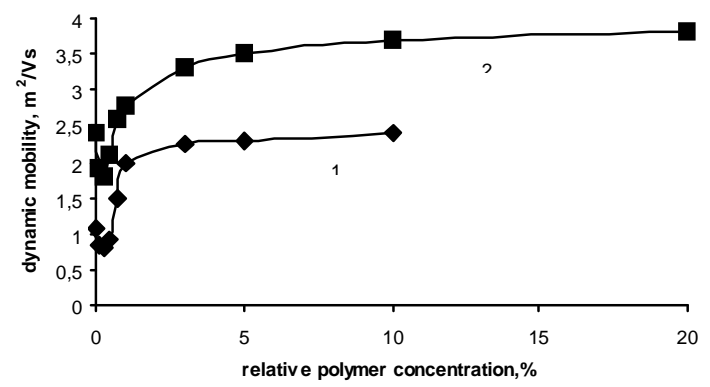

Fig. 1. Dependence of the dynamic mobility on the relative concentration of PMVE-g-PEO (G3) for $\mathrm{TiO}_{2}$ aqueous dispersion without and after ultrasonic treatment (temperature $293 \mathrm{~K}$ )

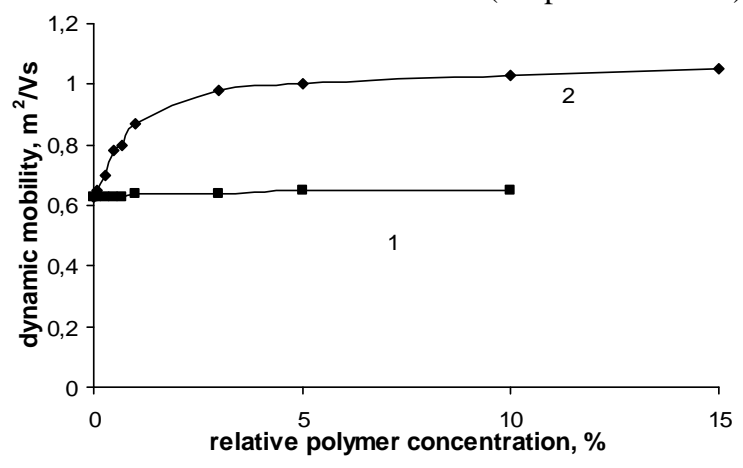

Fig. 2. Dependence of the dynamic mobility on the relative concentration of PMVE-g-PEO (G3) for CuPc aqueous dispersion after ultrasonic treatment (temperature $323 \mathrm{~K}$ )

Preliminary experiments have shown that hydrophilic polymers don't interact with hydrophobic CuPc surface in aqueous media. In case of PMVE-g-PEO copolymers, ESA measurements proved the absence of adsorption below LCST (Fig. 2, curve 1). However as it is shown by the curve 2, above LCST of PMVE, the copolymer PMVE-g-PEO is able to adsorb on the $\mathrm{CuPc}$ surface in aqueous dispersions that results in high stabilization of $\mathrm{CuPc}$ dispersion. Saturation of the adsorption layer is reached at about $3 \%$. After decreasing of the temperature, the values of dynamic mobility and $\xi$-potential are similar to those for pure $\mathrm{CuPc}$, which indicates the existence of desorption processes. This observation is in agreement with the fast coagulation process that was mentioned earlier.

\subsection{Pigment Surface Modification of CuPc with Block Copolymers}

\subsubsection{ESA studies}

$\mathrm{AB}$ and $\mathrm{ABA}$ block copolymers of methylvinyl and isobutylvinyl ethers (PMVE-PIBVE and PIBVE-PMVE-
PIBVE) exhibit a quite different thermo-responsive behavior as compared to the graft copolymers. They are amphiphilic below the LCST and become quite hydrophobic above the LCST. This gives a possibility to study their stabilizing properties in aqueous dispersions of organic pigments below and above LCST and to gain some insight into the pigment-polymer interaction and structure of the polymer layers in these systems at various temperatures.

First, aqueous dispersions of $\mathrm{CuPc}$ stabilized by $\mathrm{PMVE}_{65}-\mathrm{PIBVE}_{10}$ and $\mathrm{PIBVE}_{22}-\mathrm{PMVE}_{75}-\mathrm{PIBVE}_{22}$ (as the best colloidal stabilizers at room temperature [21]) were studied by ESA measurements (Figs. 3 and 4).

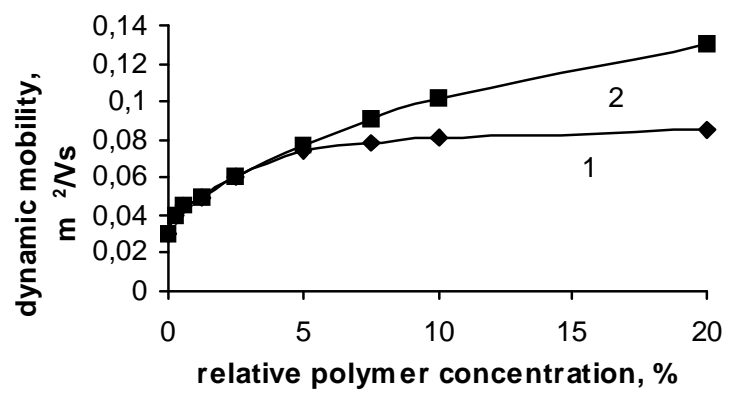

Fig. 3. Dependence of dynamic mobility of surface treated $\mathrm{CuPc}$ on the relative concentration of $\mathrm{PMVE}_{55}-\mathrm{PIBVE}_{10}$ in the aqueous dispersion in combination with ultrasonic treatment for pigment surface modification: conventional procedure (1) and LCST thermoprecipitation (2)

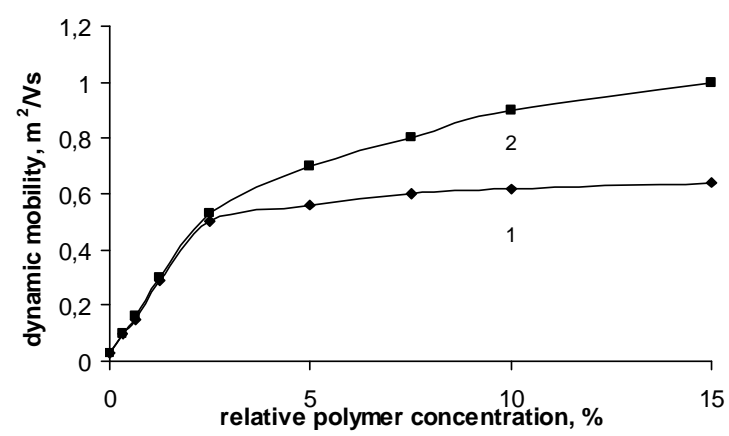

Fig. 4. Dependence of dynamic mobility of surface treated $\mathrm{CuPc}$ on the relative concentration of $\mathrm{PIBVE}_{22}-\mathrm{PMVE}_{75}-\mathrm{PIBVE}_{22}$ in the aqueous dispersion in combination with ultrasonic treatment for pigment surface modification: conventional procedure (1) and LCST thermoprecipitation (2)

Figs. 3 and 4 represent the changing of the dynamic mobility of surface modified $\mathrm{CuPc}$ dispersion with increasing amount of polymer added to the system in the surface modification. As one can see, the pigment-polymer suspensions, stabilized by di- and triblock PMVE containing copolymers below the LCST (curves 1) show quite similar behavior. The saturation of surface layer seems to be reached at $5 \%$ of $\mathrm{PMVE}_{55}-\mathrm{PIBVE}_{10}$ and $3 \%$ of $\mathrm{PIBVE}_{22}-\mathrm{PMVE}_{75}-\mathrm{PIBVE}_{22}$ in relation to the pigment. 
Further addition of block copolymer did not noticeably increase the dynamic mobility. That means that formation of thick polymolecular layers hardly occurs. The carbon black dispersions showed similar behavior.

As PMVE in aqueous solutions exhibits a lower critical solution temperature $(\mathrm{LCST}=310 \mathrm{~K})$, it was of interest to study the creation of a surface layer by the LCST technique in combination with ultrasonic treatment, which may increase the thickness of the layers and stabilization of the dispersion in comparison to the polymer deposition below LCST. The LCST technique alone has been shown to be quite efficient in pigment surface modification [23].

In this work, the procedure of dispersion preparation was slightly changed. First, in constant temperature experiments (below LCST), the isothermal condition during the ultrasonic treatment is maintained by water cooling. In comparative experiments carried out without cooling, the heat generated by the ultrasonic treatment caused the temperature of the system to rise up to $318-323 \mathrm{~K}$. As this temperature is above the LCST of PMVE, the block copolymers of PMVE became hydrophobic and were completely precipitated on the particle surface. The thickness of the deposited layers indeed increased (Figs. 3 and 4 , curves 2) and saturation concentration could not be established due to the thermoprecipitation (curves 2), which is ascribed to the fact that all polymer added to the solution precipitates on the particle surface. Thus, the more polymer is in the system, the thicker is the deposited layer, as is reflected by the higher values of dynamic mobility. This procedure gives the possibility to create surface polymer layers with controlled thickness.

\subsection{Transmission Electron Microscopy (TEM) Studies}

In order to visualize the surface modification of the pigments in aqueous dispersion by treatment with ultrasound in the presence of LCST-polymers, the aqueous dispersions were investigated by transmission electron microscopy (TEM).

The pictures of $\mathrm{CuPc}$ particles stabilized by di- and triblock PMVE copolymers after mechanical (ultrasonic) treatment only are depicted in Figs. 5 and 6. One can identify the polymer layers (grey zones) created by di- and triblock PMVE copolymers. The thickness of these layers is limited by the amount of polymer, which can be deposited on the particle surface up to saturation of polymer layer. The excess of the polymer will apparently create micelles and will not precipitate on the particles. As also seen from Figs. 5 and 6 , the thickness of the polymer layer created by triblock copolymer is higher as compared to the layer in the presence of the diblock copolymer. This is in agreement with the difference between the values of dynamic mobility obtained by ESA measurements (Figs. 3 and 4).

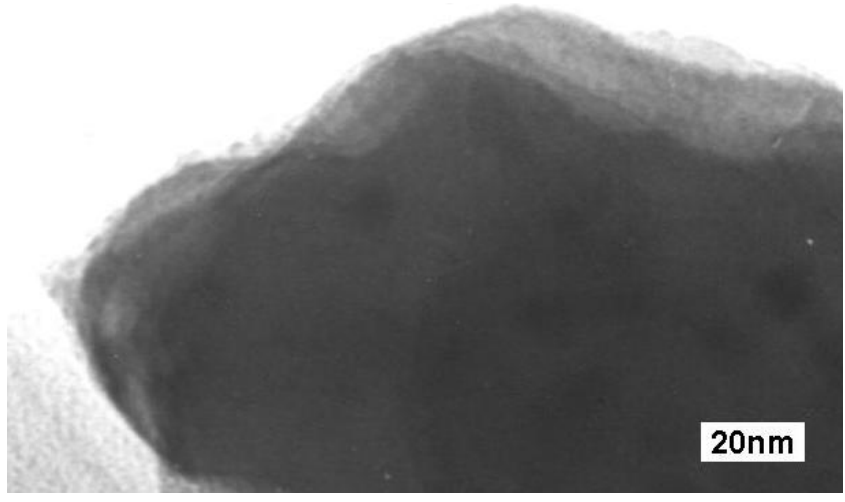

Fig. 5. Picture of $\mathrm{CuPc}$ particle in the aqueous dispersion stabilized by $\mathrm{PMVE}_{55}-\mathrm{PIBVE}_{10}$ after ultrasonic treatment. Scale $20 \mathrm{~nm}$

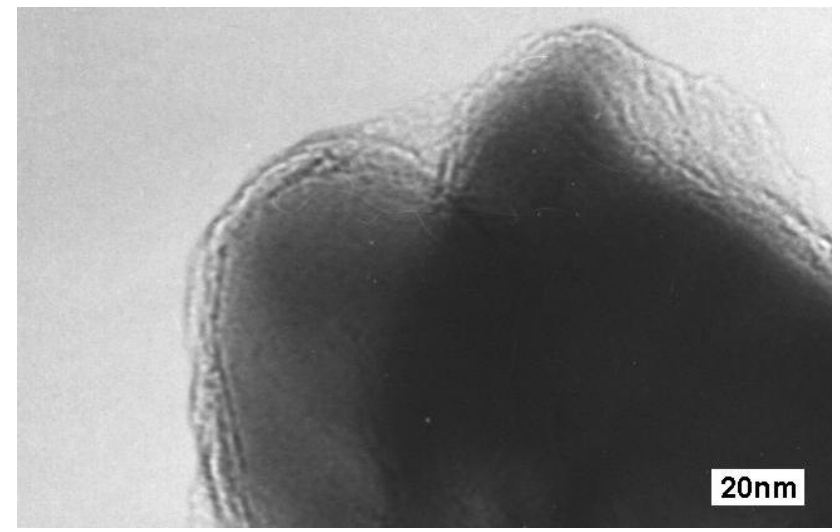

Fig. 6. Picture of $\mathrm{CuPc}$ particle in the aqueous dispersion stabilized by $\mathrm{PIBVE}_{22}-\mathrm{PMVE}_{75}-\mathrm{PIBVE}_{22}$ after ultrasonic treatment. Scale $20 \mathrm{~nm}$

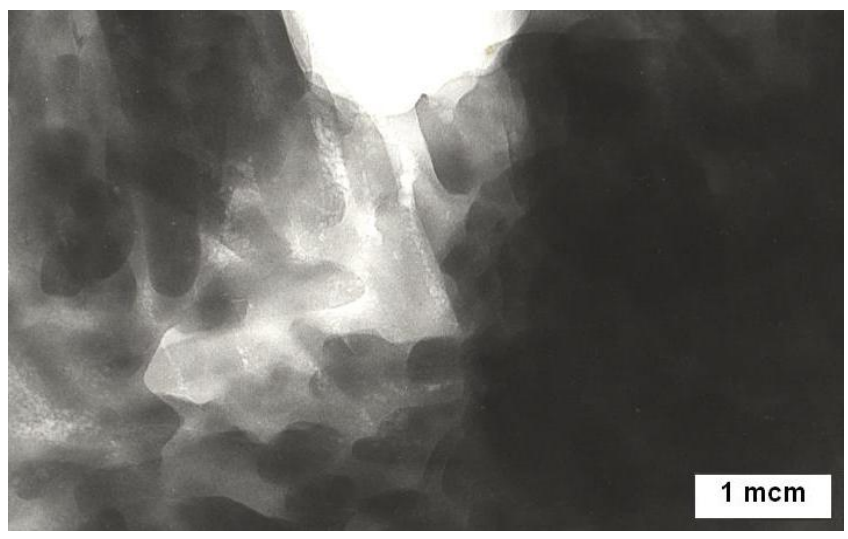

Fig. 7. Picture of $\mathrm{CuPc}$ particle in the aqueous dispersion stabilized by PMVE $_{55}-\mathrm{PIBVE}_{10}$ after ultrasonic treatment according to LCST-thermoprecipitation technique. Scale $1 \mu \mathrm{m}$

In Figs. 7 and 8, the TEM pictures of CuPc particles as covered by $\mathrm{PMVE}_{55}-\mathrm{PIBVE}_{10}$ according to the thermoprecipitation technique are given. From Fig. 7 it is inferred that thermoprecipitation of the polymer, which becomes more hydrophobic above the LCST, leads to fast coagulation of the dispersion. The particles are strongly 
aggregated, with aggregate size of $5-10 \mu \mathrm{m}$. The polymer layer is much thicker in comparison to the layer thickness resulting from conventionally prepared systems (Fig. 8). After decreasing of the temperature below LCST, the PMVE copolymer becomes amphiphilic and partial desorption of the polymer is observed; thus the system can be redispersed. In order to retain the thickness of the adsorption layer, one can consider a system in which the polymer can be crosslinked to prevent the desorption process (cf. [23]).

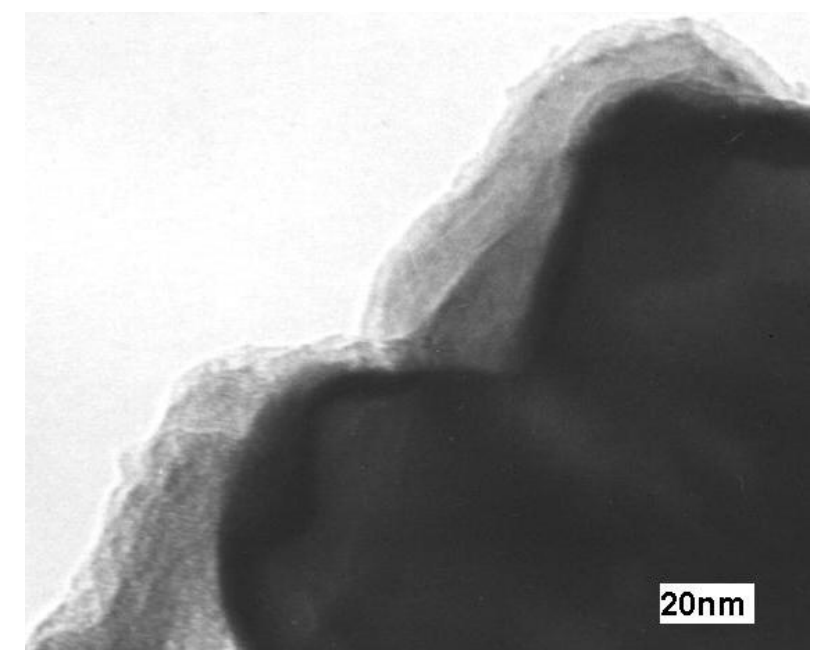

Fig. 8. Picture of $\mathrm{CuPc}$ particle in the aqueous dispersion stabilized by $\mathrm{PMVE}_{55}-\mathrm{PIBVE}_{10}$ after ultrasonic treatment according to LCST-thermoprecipitation technique. Scale $20 \mathrm{~nm}$

\section{Conclusions}

The temperature-controlled sorption of the PMVEg-PEO copolymers on both inorganic and organic pigment surfaces was investigated. It was shown that depending on the temperature those polymers can adsorb on both hydrophilic and hydrophobic pigment surface. This gives a possibility to use these PMVE graft copolymers as universal smart surfactants for surface modification of both polar inorganic and non-polar organic pigments and for temperature-controlled interaction.

Block copolymers containing PMVE and hydrophobic blocks were shown to act as temperature-controlled stabilizers of $\mathrm{CuPc}$, carbon black and $\mathrm{TiO}_{2}$ aqueous dispersions. Mechanical treatment of dispersed pigment systems proven not only enhances the dispersion stability, but also influences the pigment-polymer interaction. It was further observed that the precipitation of polymers or polymer segments on the particle surface by exceeding the LCST is much more efficient than isothermal deposition below LCST for creation of thick polymolecular polymer layers on the particles surface.

\section{References}

[1] Holmberg K., Jönsson B., Kronberg B. and Lindman B.: Surfactants and Polymers in Aqueous Solution", $2^{\text {nd }}$ edn. J. Wiley \& Sons, Chichester, UK 2003.

[2] Netz R. and Andelman D.: Physics Reports, 2003, 380, 1.

[3] Somasundaran P. and Krishnakumar S.: Colloids Surfaces A,1997, 123, 491.

[4] Theo G. and de Ven V.: Adv. Colloid Interface Sci., 1994, 48, 121.

[5] Somasundaran P. and Yu X.: Adv. Colloid \& Interface Sci., 1994, 53, 33

[6] Zubov V., Kuzkina I., Ivankova I and Schmitz O.: Eur. Coating J., 1998, 12, 954.

[7] Zubov V., Kuzkina I., Ivankova I. and Schmitz O.: Eur. Coating J., 1998, 11, 856.

[8] Antonietti M. and Weissenberger M.: Macromol. Rapid. Com., 1997, 18, 295.

[9] Zubov V., Serebryakova N., Arutyunov I. et al.: Colloid J., 2004, 66, 302.

[10] O’Brien R.: J. Fluid Mech., 1988, 190, 71.

[11] O'Brien R., Midmore B., Lamb A. and Hunter R.: Faraday Discuss. Chem. Soc., 1990, 90, 301.

[12] Loewenberg M. and O'Brien R.: J. Colloid Interface Sci., 1992, 150, 158.

[13] Rider P. and O'Brien R.: J. Fluid. Mech., 1993, 257, 607.

[14] Maier H., Baker J. and Berg J.: J. Colloid Interface. Sci., 1987, 119, 512.

[15] Miller N. and Berg J.: Colloids and Surfaces, 1991, 59, 119.

[16] Carasso M., RowlandsW. and O'Brien R.: J. Colloid Interface Sci., 1997, 193, 200.

[17] O’Brien R.: Part. Syst. Charact., 2002, 19, 1.

[18] Eisenbach C., Schaller Ch., Schauer T. and Dirnberger K.: ACS Symposium Series 881 "Particle Sizing and Characterization", American Chemical Society, 2004, 215.

[19] Schaller C., Schoger A., Dirnberger K. et al.: Macromol. Symp., 2002, 179, 173.

[20] Schaller C., Schauer T., Dirnberger K. and Eisenbach C.: Eur. Phys. J., 2001, E 6, 365.

[21] Bulychev N., Arutunov I., Zubov V. et al.: Macromol. Chem. Phys., 2004, 205, 2457.

[22] Goethals E., Reyntjens W., Zhang X. et al.: Macromol. Symp., 2000, 157, 93.

[23] Schauer T. and Eisenbach C.: ECJ, 2003, 3, 114.

\section{МОДИФІКАЦІЯ ПОВЕРХНІ У ВОДНИХ ДИСПЕРСНИХ СИСТЕМАХ ТЕРМОЧУТЛИВИМИ КОПОЛІМЕРАМИ ПОЛІМЕТИЛВІНІЛОВОГО ЕТЕРУ У ПОСДНАННІ 3 УЛЬТРАЗВУКОВИМ вПЛИВОМ}

Анотація. Досліджено проиес модифікації поверхні гідрофобних органічних пігментів (фталочіаніну міді та сажі) $i$ гідрофільного неорганічного пігменту діоксиду титану у водних дисперсних системах з використанням спещіально синтезованих термочутливих кополімерів та колоїдна стабільність отриманих дисперсних систем. Модифікачія поверхні пігментів проводилась звичайною адсорбиією $i$ термоосадженням амфіфільних блочних $і$ прищеплених кополімерів метилвінілового етеру, які містять сегменти оксиду поліетилену та мають нижню критичну температуру розчинності (НКТР). Дослід- 
жено вплив ультразвукового оброблення дисперсних систем пігментів у поєднанні з використанням властивостей НКТР. Прочес модифікації поверхні пігментів досліджено за допомогою електрокінетичної звукової амплітуди. Досліджено проиес температурно-контрольованої сорбиії прищчеплених кополімерів ПМВЕ-g-ПЕО на поверхні неорганічних $і$ органічних пігментів. Встановлено, що ультразвуковий вплив у поєднанні з термоосадженням є перспективним способом модифікації поверхні пігментів і одержсання дисперсних систем високої стабільності.

Ключові слова: термочутливі полімери, ультразвуковий вплив, водні дисперсні системи, неорганічні пігменти, органічні пігменти, нижня критична температура розчинності. 